\title{
Payment for forest environmental services: a meta-analysis of successful elements
}

\author{
Geremia Gios, Dina Rizio
}

Forest ecosystems produce environmental services from which individuals benefit. In recent decades, interest in these services has significantly increased to meet the demand for new products and services related to landscape use and recreational activities. These new products and services are defined as Non-Wood Forest Products and Services (NWFP\&Ss). There is the possibility, and in certain cases the need, to introduce a system of payment for these NWFP\&Ss. However, the transformation of forest environmental goods and services into commercial products and services is not a straightforward process. This paper reviews a number of successful payment mechanisms for NWFP\&Ss in order to examine the elements which contribute to transforming these externalities into sources of income for people living near forests.

Keywords: Payment For Environmental Services (PES), Forest Resources, Nonwood Forest Products And Services, Landscape, Tourism

\section{Introduction} tion of payment mechanisms for Non-Wood Forest Products and Services (NWFP\&Ss) has grown steadily, due mainly to the need to support sustainable forest development and management. In this context, the concept of the long term sustainability of forests is closely related to the interest of local populations in managing and preserving forests (Agrawal \& Gibson 1999, Nagendra 2011). Command and control mechanisms are a possible alternative, although they do not guarantee the long term sustainability of forests: the role of local populations appears to be crucial.

Sustainable approaches are intended to diversify and increase the incomes of communities whose economies are based on forest resources. However, the transformation of environmental goods and services associated with forests into commercial products and services is not a straightforward matter, depending, as it does, upon both endogenous and exogenous factors. Various methods have been proposed to overcome the difficulties associated with transforming forest externalities into real sources of income (Merlo et al. 2000, Wunder 2005, Pettenella \& Secco 2006, Wunder et al.
In recent decades, interest in the introduc-

\section{8).}

A set of NWFP\&Ss may be included within the benefits and recreational activities made available by landscape fruition, that is, by considering a combination of three main values: scenic beauty or landscape value, recreational value, evocative value. Of these, the first two are use values. As regards use value, it is possible to make further distinctions related to the type of use where the landscape is a basic background for activities, or the principal or accessory resource for recreational activities (Dillman \& Bergstrom 1991). Therefore, landscape may be seen as a public good and therefore cost free for users. It is an externality. In this context, the landscape provided by the forest can be subjected to same issues shown before and the externality it produces may represent potential source of income if there are users available to pay to enjoy them.

This paper examines several case studies on the implementation of PES mechanisms, focusing on the factors which facilitate the transformation of these externalities into sources of income for people living near forests.

After a brief examination of the fundamental requirements of payment mechanisms for environmental services (PES), the paper exa-

University of Trento, via Inama, 5 I-38122, Trento (Italy)

@ Dina Rizio (dina.rizio@unitn.it)

Received: Jul 27, 2012 - Accepted: Jan 09, 2013

Citation: Gios G, Rizio D, 2013. Payment for forest environmental services: a meta-analysis of successful elements. iForest 6: 141-149 [online 2013-04-08] URL: http://www.sisef.it/ iforest/contents/?id=ifor0707-006

Communicated by: Marco Borghetti mines the interactions between NWFP\&Ss and forest landscapes. Next, five ways in which these interactions can be made explicit will be analyzed: the scenic beauty of the landscape, the recreational use of landscape, adventure parks, mountain chalets, mushrooms and truffles gathering, wood handicraft supply chain and theme trails. Finally, elements that have positively contributed to PES implementation will be examined and highlighted.

\section{Forest products and services}

From an anthropocentric perspective, ecosystem services are "benefits people obtain from ecosystems" (Millennium Ecosystem Assessment 2003). Although general, this definition views forest products and services as ecosystem processes and functions of value to human beings. Thus, the value of ecosystem services may be based in people's needs rather than having any intrinsic value. However, if an ecosystem is separated from its complex set of functions and features and viewed only from a marketing perspective (McCauley 2006), this view may be challenged on the grounds that it underestimates the complexity of ecosystems and suggests inappropriate uses for it, given the highly complex reality of any ecosystem (Norgaard 2010).

However, other authors welcome the opportunity to consider environmental services in terms of their value for humanity (Brown 1984, Zube 1987, Manning et al. 1999). While recognizing its limitations, this approach may be useful to sustainable development. Furthermore, attributing an economic value to environmental resources and services implies inducing people to pay for these environmental services and thus to preserve the resource that supplies them (Turner et al. 2003, Elsasser et al. 2009). From the point of view of sustainability, the willingness to pay for such services can be considered a theoretical basis (Wunder 2005, Engel et al. 2008) for environmental taxes, command and control mechanisms, and integrated conservation and development projects (World Bank 2003, Engel et al. 2008). Under certain conditions, the willingness to pay can generate financial incentives for local actors to transform the value of natural resources into goods and services (Turner et al. 2003, Muradian et al. 2010). When the willingness to pay is formalized and results in a PES, environmental services can be introduced to markets in which they are not normally available. However, the value of these services is not well defined because the resources upon which they are based are often considered, at least partially, to be a public good.

Wunder (2005) suggests four key characteristics of PES mechanisms: voluntary transactions, well-defined environmental services 
or land use that ensures the availability of those services, the presence of at least one buyer and one provider in the market and a certain degree of reliability in the provision of the service. Most cases do not include all four of these elements and so a mechanism resembling a PES (PES-like) is created, which is not entirely consistent with the theoretical model mentioned above (Wunder et al. 2008, Van Noordwijk \& Leimona 2010).

The most frequent deviations from the basic PES model involve the type of incentive proposed, the degree of voluntariness of the transaction, the allocation of property rights and sales, the extent to which the PES is debated locally and the presence of a clear link between the service provided and the actual work setting (Wunder 2005).

According to Wunder (2005), key defining attributes of a PES are that the mechanism be realistic, voluntary and conditional. The ability of a PES to fulfill these conditions varies from situation to situation and its outcome will be influenced by the problems inherent in the situation when the mechanism begins to be implemented.

According to Van Noordwijk \& Leimona (2010) the attributes realistic, voluntary and conditional are attributes of effectiveness (defined in terms of the cause and effect relationship between the explicit acknowledgement of the service provision for which there may be something to pay and the action of payment). These authors identify two other essential attributes: efficiency (as a ratio of the implementation cost of the PES mechani$\mathrm{sm}$ to the revenue derived from the payment mechanism) and equity (in revenue distribution providing income to local populations).

\section{Landscape use and recreational activities in the forest}

In recent decades the forest has come to be recognized as more than just a source of timber; it can also cater to social needs and allow for new forms of resource use (Reimoser 2005). It is difficult to define the rural landscape as a commodity. One definition views it as a "permanent creative process" (Tabet 1963). This entails a twofold investigation of the landscape concept. The first relates to the elements which contribute to physically changing the landscape, the second to an analysis of the dynamic process through time which modifies and develops the landscape, as will be discussed later on (Gios \& Clauser 2009).

The transformation of goods and services associated with the use of the natural landscape and recreational activities into marketable products and services is not straightforward, particularly when dealing with forest resources. As noted by several authors (Merlo et al. 2000, Wunder 2005, Pettenella \& Secco 2006, Wunder et al. 2008), different methods and channels exist for the transfor- mation of services, products and externalities of traditional forest management into innovative and profitable products and services.

From a user's perspective, the value of the natural landscape is the sum of three components: the scenic, recreational and evocative values (Dillman \& Bergstrom 1991). A first distinction for these three components is the use value, derived from the direct use of resources. Considering the three values above, the evocative has no use value, while the scenic and recreational components can be assigned a use value.

The scenic component, which combines several aesthetic qualities, is composed of other values.

The landscape must be regarded as a set of goods rather than as a single product. In particular, within a different framework in which landscape is related to a forest there are at least three possible viewpoints; according to Clawson et al. (1960) the forest landscape can be understood as follows:

1. as completely or partially user-oriented;

2. as a "container" for resources facilitating the recreational use of the resources;

3. as a background.

The viewpoint chosen will depend on the predominant recreational or scenic value.

Within the framework of landscape use, these different understandings of the landscape will result in different levels of excludability from the mentioned landscape use.

These different degrees of excludability limit the creation of an effective market for the landscape as a commodity. It is not easy to identify a clear link between a product introduced onto the market and the payment requested for that product (the effectiveness attribute), and the identification of producers and beneficiaries is equally complicated. The cultural aspects influencing the interpretation of landscape should not be underestimated (Goio \& Gios 2011). Thus, it is important that all attempts to apply a PES to a forest landscape should first identify the specific characteristics of that landscape.

In general, the transformation of environmental goods and services into marketable products involves both institutional and adhoc interventions at different levels and a commitment to the promotion of those products (Merlo et al. 2000). The transformation also implies the redistribution of roles and benefits and the recruitment and training of human capital. Efficiency, effectiveness, an equitable division of costs and benefits and control over the cost of identifying and managing free riders are crucial to the transformation.

So, Wunder's key attributes (Wunder 2005 ) need to be combined with other requirements, such as efficiency, effectiveness and equity distribution. These attributes come to the fore when attention shifts from the theoretical background to the consequences of PES implementation (Gatto et al. 2009, Van Noordwijk \& Leimona 2010).

\section{Description of NWFP\&Ss}

From the consumer's perspective, NWFP\&Ss can be grouped into three categories: mass, specialized and complementary products and services (Niskanen et al. 2007).

The analysis of these inputs according to marketing-mix theory (4 Ps) shows that product, price and cost minimization are crucial factors for mass products and services. Promotion is usually supported by brand creation, often linked to the history or territorial uniqueness of the area. The success of this group of NWFP\&Ss depends on factors such as the human and social capital involved, weather conditions, the seasonality of products and services, and product perishability. Non-Wood Forest Products and Services are defined as specialized products and services when certain conditions are met. These specialized products and services have high added value. However, their availability is limited by quantity and environmental or seasonal conditions. Their target market is small. Even when this is the case, within the marketing mix, the product is very important, particularly because of its direct association with quality. However, the risk that products will be imitated is high and so promotional activities remain an important vehicle of differentiation. These activities include the use of environmental and certification labels and alternative merchandising channels, such as web retail (Box 1).

The main feature of complementary products is the combination of relationships and territorial linkages, which provide complementary products and services with features and values that differentiate them from similar products on the market in other areas. Precisely because of these territorial linkages, networking and cooperation between local institutions and the business sector is difficult and creates complex product systems. Products may include more than those obtained from the primary fruition of resources, also covering services like accommodation, food and wine, local customs and traditions. The complementary NWTFP\&Ss play a strategic role in the promotion of local rural development strategies that invigorate local businesses and networks (Pettenella \& Maso 2009). Two other elements can be added to the traditional 4Ps marketing mix: political power and political participation. Where this addition is possible, the complementary NWFP\&Ss manifest unique features associated with participation, political support and strong interaction between public and private stakeholders (Pettenella \& Secco 2006).

\section{PES Case studies and the methodological framework}

Based on an extensive review of the litera- 


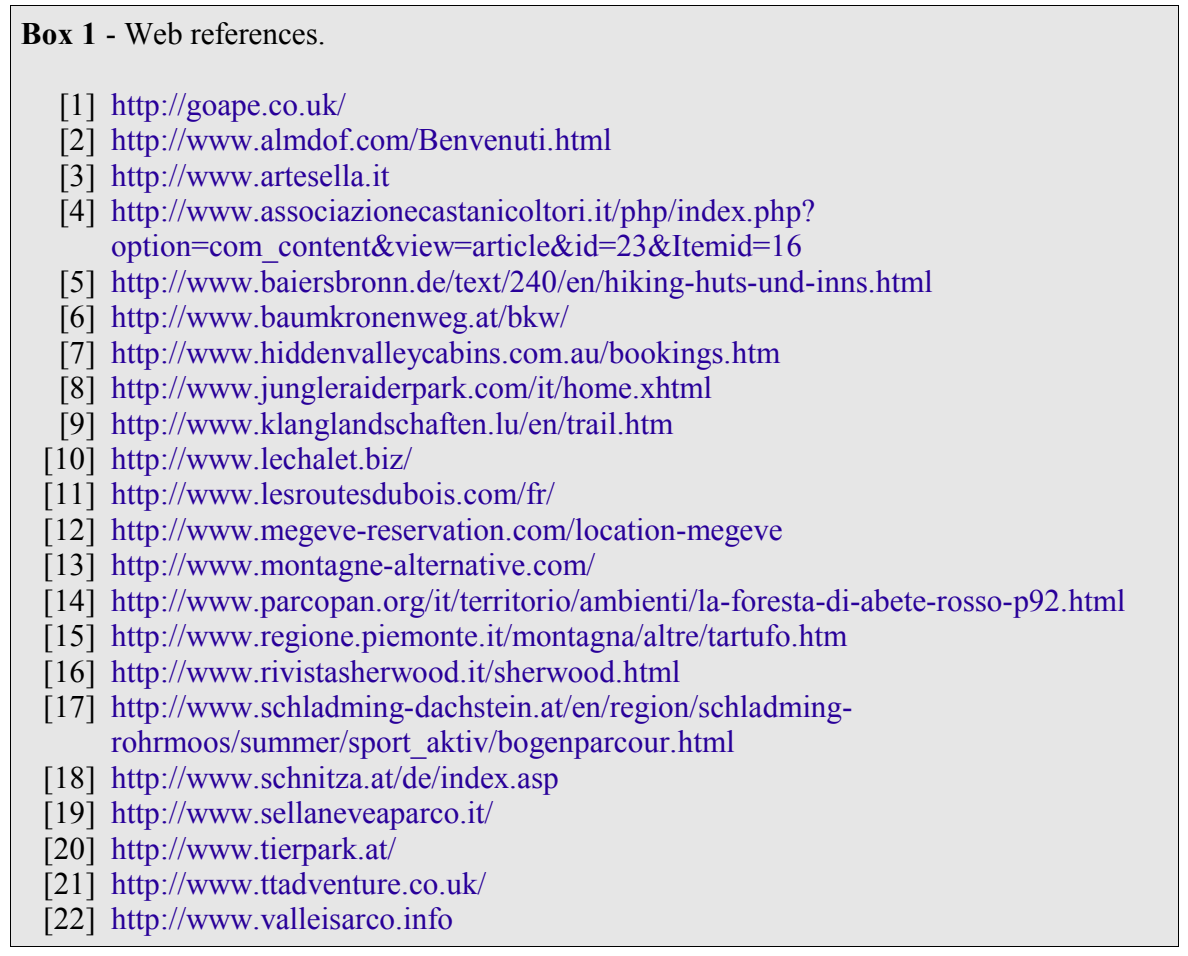

ture, PESs related to landscape use and recreational activities are grouped thus: landscape (scenic beauty and recreation) - Tab. 1 , adventure parks - Tab. 2, mountain chalets

Tab. 3, wood handicraft supply chains Tab. 4 and theme trails, mushrooms and truffles gathering - Tab. 5 .

The literature related to case study analysis of the implementation of PES mechanisms for NWFP\&Ss has been examined in detail and a selection of those which the authors believe to be successful is given.

A further analysis of these case studies is then conducted in order to discover the reasons for their success. All these factors have been taken into account and analyzed collectively in order to identify the most powerful and important of them. A 1-2-3 score was then used to compare these elements and provide a graphic representation.

The five groups listed above were created by selecting case studies of successful PES mechanisms. They are grouped according to product type.

\section{Elements driving successful PES mechanism implementation}

This analysis of successful case studies allows us to list a number of elements which are either driving or contributing to successful performances of the PES mechanism. The recognition of an environmental resource as a product or service is an important first step in the creation of a PES. When this occurs, the environmental resource is clearly identified as a product or service and it is understood that a price should be paid to access it. This step may not be taken for gran- ted, and although the process is sometimes straightforward, it is often difficult to establish a connection between a product or service and an environmental resource. There are several reasons for these difficulties. One of the most common problems is the identification of the environmental resource as a commercial product or service. Environmental resources are usually considered to be public and are not immediately identified as products or services to be paid for. Therefore, clearly identifying the functions and features of the managing authority and the environmental resource is essential. The environmental resource must be identified and the resource's availability and affordability as a service or product must be communicated to users.

The next key step must be taken if this environmental product or service is to be recognized as worth paying for and its providers remunerated through a PES mechanism. This emerges clearly as a second success element. To guarantee effective results, the relationship between the product or service and the price must be clear. Accepting the need to pay for a resource implies accepting its value, and the obligation to pay the providers of that resource for its use.

In the studies considered, many goods are recognized as services or products when the creation of added value is clear. Although in the literature, the UK case study for example, the forest landscape is considered an environmental resource that can generate payments, the value of the forest landscape is properly acknowledged when the landscape is linked to other values that complete it and add value. Payment can then usually be demanded for using the environmental resources concerned.

Landscape, along with the culture, tradition and human capital that has changed and modeled it, are the resources upon which a PES mechanism can be constructed.

A third essential element is the identification of the environmental product or service with the entire destination. This identification is more straightforward because the product in question has a widely recognized value. In the cases analyzed, exclusivity and typical local features are the recognized value. In many cases, the success of the products lies precisely in an embedded policy of differentiation in terms of product quality and uniqueness. The product is defined as unique, exclusive and high quality because of a strong territorial connotation. The element of forestry and land management as a whole is fully included as an essential condition for the production of that product or service.

A fourth key to success is the creation of local networks and synergies which lead the entire destination to support a PES. The destination refers to the entire system, combining local stakeholders who interact with the PES at different levels with the additional value of the resource in question. In many cases, the correlation between the product or service and the skills within the area is not immediate and/or regular. Local companies usually only begin to network to create an effective and integrated system after a PES has been implemented and they sometimes require the support of external authorities or public agencies to ensure that this integration occurs (i.e., business consortia and tourist offices).

This public support often takes the form of certifications or similar broadly effective mechanisms (i.e., typical product labels or indications of geographical origin) to ensure a more effective return for the destination image. The network and the creation of synergies mentioned earlier are made even more effective when supported by public bodies. This support is expressed both through active involvement on the part of these institutions and through increased access to funding. In the cases where PESs have been successful it was the institutions and management authorities who dealt with the legal bureaucracy, both formal and informal, involved in implementing a new PES. In addition to the efforts of these stakeholders, local associations and organizations interact at different levels to create a solid foundation for mutual cooperation and consultation.

A very important fifth element is the clear assignment of property rights. Where PESs have been successful, they have involved stakeholders with explicit rights to the property in question. In some cases, the alloca- 
Tab. 1 - Landscape.

\begin{tabular}{llllll}
\hline $\begin{array}{l}\text { Product/ } \\
\text { Service }\end{array}$ & Location & $\begin{array}{l}\text { Marketable } \\
\text { Product/ Service }\end{array}$ & Who buys & Who sells & Source \\
\hline $\begin{array}{l}\text { Landscape and } \\
\text { scenic beauty }\end{array}$ & Costa Rica & $\begin{array}{l}\text { Landscape management and } \\
\text { enhancement of scenic beauty } \\
\text { and landscape }\end{array}$ & $\begin{array}{l}\text { Fonafifo (National Autonom- } \\
\text { ous Authority) }\end{array}$ & $\begin{array}{l}\text { Local community and } \\
\text { landowners }\end{array}$ & Pagiola 2008 \\
\hline $\begin{array}{l}\text { Landscape and } \\
\text { scenic beauty. }\end{array}$ & UK & $\begin{array}{l}\text { Improvement and enhance- } \\
\text { ment of recreational activities } \\
\text { Recreational } \\
\text { activities }\end{array}$ & $\begin{array}{l}\text { The UK government and the } \\
\text { related to natural resources } \\
\text { and national financial support) }\end{array}$ & Farmers from selected areas & $\begin{array}{l}\text { Dobbs \& } \\
\text { Pretty 2008 }\end{array}$ \\
\hline $\begin{array}{l}\text { Recreational } \\
\text { activities: safari }\end{array}$ & $\begin{array}{l}\text { Zimbabwe } \\
\text { (Campfire) }\end{array}$ & $\begin{array}{l}\text { Biodiversity conservation and Tourism operators and NGO } \\
\text { enhancement of access to re- } \\
\text { sources }\end{array}$ & $\begin{array}{l}\text { Local communities through } \\
\text { the direction of the local rural } \\
\text { council }\end{array}$ & $\begin{array}{l}\text { Frost \& Bond } \\
2008\end{array}$ \\
\hline
\end{tabular}

Tab. 2 - Adventure parks.

\begin{tabular}{|c|c|c|c|c|c|}
\hline $\begin{array}{l}\text { Product/ } \\
\text { Service }\end{array}$ & Location & $\begin{array}{l}\text { Marketable } \\
\text { Product/Service }\end{array}$ & Who buys & Who sells & Source \\
\hline Go Ape & UK & Adventure parks & Private agents & $\begin{array}{l}\text { Private agents/ } \\
\text { manager }\end{array}$ & http://goape.co.uk/ \\
\hline $\begin{array}{l}\text { Tree Top } \\
\text { Adventure }\end{array}$ & $\begin{array}{l}\text { UK } \\
\text { (Wales) }\end{array}$ & Adventure park in Wales & Private agents & $\begin{array}{l}\text { Private agents/ } \\
\text { manager }\end{array}$ & http://www.ttadventure.co.uk/ \\
\hline $\begin{array}{l}\text { Jungle Raider } \\
\text { Park }\end{array}$ & $\begin{array}{l}\text { Italy } \\
\text { (Como and } \\
\text { Lecco } \\
\text { provinces) }\end{array}$ & Two adventure parks & Private agents & $\begin{array}{l}\text { Private agents/ } \\
\text { manager }\end{array}$ & $\begin{array}{l}\text { http://www.jungleraiderpark.com/it/ho } \\
\text { me.xhtml }\end{array}$ \\
\hline $\begin{array}{l}\text { Adventure park } \\
\text { Sella Nevea }\end{array}$ & $\begin{array}{l}\text { Italy } \\
\text { (Carnia area) }\end{array}$ & Adventure Park & Private agents & $\begin{array}{l}\text { Private agents/ } \\
\text { manager }\end{array}$ & $\begin{array}{l}\text { http://www.sellaneveaparco.it/ and } \\
\text { Wiesinger } 2009\end{array}$ \\
\hline $\begin{array}{l}\text { Bruno's Bogen- } \\
\text { parcours }\end{array}$ & Austria & Archery with $3 \mathrm{D}$ targets & $\begin{array}{l}\text { Visitors and } \\
\text { users }\end{array}$ & - & $\begin{array}{l}\text { http://www.schladming- } \\
\text { dachstein.at/en/region/schladming-rohr- } \\
\text { moos/summer/sport_aktiv/bogenpar- } \\
\text { cour.htm and Weisinger } 2009\end{array}$ \\
\hline $\begin{array}{l}\text { Wildpark } \\
\text { Buchenberg }\end{array}$ & Austria & $\begin{array}{l}\text { Olympic game of forest activities } \\
\text { (archery, crossbow, activities } \\
\text { related to woodcutting). }\end{array}$ & $\begin{array}{l}\text { Visitors and } \\
\text { users }\end{array}$ & - & $\begin{array}{l}\text { http://www.tierpark.at/ and Weisinger } \\
2009\end{array}$ \\
\hline
\end{tabular}

Tab. 3 - Mountain Chalets.

\begin{tabular}{|c|c|c|c|c|c|}
\hline $\begin{array}{l}\text { Product/ } \\
\text { Service }\end{array}$ & Location & $\begin{array}{l}\text { Marketable } \\
\text { Product/Service }\end{array}$ & Who buys & Who sells & Source \\
\hline $\begin{array}{l}\text { Almdorf, } \\
\text { Seinerzeit }\end{array}$ & $\begin{array}{l}\text { Austria } \\
\text { (Carinthia) }\end{array}$ & $\begin{array}{l}\text { Tourist accommodation for } \\
\text { tourists and recreation }\end{array}$ & $\begin{array}{l}\text { Private users/ } \\
\text { visitors }\end{array}$ & Private managers & $\begin{array}{l}\text { http://www.almdof.com/Benven- } \\
\text { uti.html }\end{array}$ \\
\hline $\begin{array}{l}\text { Montagne- } \\
\text { Alternative }\end{array}$ & Switzerland & $\begin{array}{l}\text { Tourist accommodation for } \\
\text { tourists and recreation }\end{array}$ & $\begin{array}{l}\text { Private users/ } \\
\text { visitors }\end{array}$ & Private managers & $\begin{array}{l}\text { http://www.montagne-alternative.- } \\
\text { com/ }\end{array}$ \\
\hline La taïga & Switzerland & $\begin{array}{l}\text { Tourist accommodation for } \\
\text { tourists and recreation }\end{array}$ & $\begin{array}{l}\text { Private users/ } \\
\text { visitors }\end{array}$ & Private managers & $\begin{array}{l}\text { http://www.megeve-reservation.- } \\
\text { com/location-megeve }\end{array}$ \\
\hline $\begin{array}{l}\text { Le Chalet } \\
\text { Tournesol }\end{array}$ & France & $\begin{array}{l}\text { Tourist accommodation for } \\
\text { tourists and recreation }\end{array}$ & $\begin{array}{l}\text { Private users/ } \\
\text { visitors }\end{array}$ & Private managers & http://www.lechalet.biz/ \\
\hline $\begin{array}{l}\text { Hidden Valley } \\
\text { Cabins }\end{array}$ & Australia & $\begin{array}{l}\text { Tourist accommodation for } \\
\text { tourists and recreation }\end{array}$ & $\begin{array}{l}\text { Private users/ } \\
\text { visitors }\end{array}$ & Private managers & $\begin{array}{l}\text { http://www.hiddenvalleycabins.- } \\
\text { com.au/bookings.htm }\end{array}$ \\
\hline $\begin{array}{l}\text { Destination } \\
\text { Baiersbronn }\end{array}$ & $\begin{array}{l}\text { Baiersbronn, } \\
\text { Germany }\end{array}$ & $\begin{array}{l}\text { Tourist accommodation and } \\
\text { hospitality for tourists and } \\
\text { recreation }\end{array}$ & $\begin{array}{l}\text { Local and } \\
\text { foreign visitors }\end{array}$ & $\begin{array}{l}\text { Private managers } \\
\text { and various stake- } \\
\text { holders }\end{array}$ & $\begin{array}{l}\text { http://www.baiersbronn.de/text/240 } \\
\text { /en/hiking-huts-und-inns.html }\end{array}$ \\
\hline $\begin{array}{l}\text { Baumkronen- } \\
\text { weg/Baum- } \\
\text { hotel }\end{array}$ & Austria & $\begin{array}{l}\text { Tourist accommodation and } \\
\text { other facilities and activities } \\
\text { for tourists and recreation }\end{array}$ & $\begin{array}{l}\text { Private users/ } \\
\text { visitors }\end{array}$ & Private managers & $\begin{array}{l}\text { http://www.baumkronenweg.at/bk } \\
\text { w/ } \\
\text { and Wiesinger } 2009\end{array}$ \\
\hline $\begin{array}{l}\text { La suite della } \\
\text { quercia }\end{array}$ & Italy & $\begin{array}{l}\text { Tourist accommodation for } \\
\text { tourists and recreation }\end{array}$ & $\begin{array}{l}\text { Private users/ } \\
\text { visitors }\end{array}$ & Private managers & Wiesinger 2009 \\
\hline
\end{tabular}


Tab. 4 - Wood handicraft supply chain and theme trails.

\begin{tabular}{|c|c|c|c|c|c|}
\hline $\begin{array}{l}\text { Product/ } \\
\text { Service }\end{array}$ & Location & $\begin{array}{l}\text { Marketable } \\
\text { Product/Service }\end{array}$ & Who buys & Who sells & Source \\
\hline $\begin{array}{l}\text { Resonant } \\
\text { spruce wood } \\
\text { (a) }\end{array}$ & $\begin{array}{l}\text { Italy, Trentino } \\
\text { (Paneveggio province- } \\
\text { owned forests) }\end{array}$ & $\begin{array}{l}\text { Resonant spruce } \\
\text { wood }\end{array}$ & $\begin{array}{l}\text { Luthiers and private } \\
\text { producers of sound } \\
\text { boxes for musical } \\
\text { instruments }\end{array}$ & $\begin{array}{l}\text { Manager of the local } \\
\text { province-owned forests } \\
\text { (APROFOD) }\end{array}$ & Zugliani \& Dotta 2009 \\
\hline $\begin{array}{l}\text { Resonant } \\
\text { spruce wood } \\
\text { (b) }\end{array}$ & $\begin{array}{l}\text { Italy, Trentino } \\
\text { (Collective ownership } \\
\text { "Magnifica Comunità } \\
\text { di Fiemme", the violin } \\
\text { forest) }\end{array}$ & $\begin{array}{l}\text { Resonant spruce } \\
\text { wood }\end{array}$ & $\begin{array}{l}\text { Luthiers and private } \\
\text { producers of sound } \\
\text { boxes for musical } \\
\text { instruments }\end{array}$ & $\begin{array}{l}\text { Manager of the collec- } \\
\text { tively owned } \\
\text { "Magnifica comunità } \\
\text { di Fiemme" }\end{array}$ & $\begin{array}{l}\text { http://www.parcopan.org/it/ter } \\
\text { ritorio/ambienti/la-foresta-di- } \\
\text { abete-rosso-p92.html }\end{array}$ \\
\hline Arte Sella & Italy, Trentino & $\begin{array}{l}\text { Open-air museum } \\
\text { located in a forest }\end{array}$ & $\begin{array}{l}\text { Visitors and users } \\
\text { of the museum }\end{array}$ & Museum manager & $\begin{array}{l}\text { http://www.rivistasherwood.it/ } \\
\text { sherwood.html; } \\
\text { http://www.artesella.it }\end{array}$ \\
\hline Sound trails & $\begin{array}{l}\text { Natural Park of Our } \\
\text { (Hoscheid, in France, } \\
\text { Belgium, and } \\
\text { Luxemburg) }\end{array}$ & $\begin{array}{l}\text { Belonging to the } \\
\text { Wood routes } \\
\text { project }\end{array}$ & $\begin{array}{l}\text { Visitors and users } \\
\text { of the Natural Park } \\
\text { of Our }\end{array}$ & Natural Park of Our & $\begin{array}{l}\text { http://www.lesroutesdubois.- } \\
\text { com/fr/, http://www.klang- } \\
\text { landschaften.lu/en/trail.htm }\end{array}$ \\
\hline Holzpark & Austria & $\begin{array}{l}\text { Area equipped with } \\
\text { woodworking faci- } \\
\text { lities within a forest }\end{array}$ & - & - & $\begin{array}{l}\text { http://www.schnitza.at/de/in- } \\
\text { dex.asp }\end{array}$ \\
\hline $\begin{array}{l}\text { Chestnut } \\
\text { distribution } \\
\text { chain }\end{array}$ & Alto Adige, Italy & Chestnut trails & Visitors and users & - & http://www.valleisarco.info \\
\hline $\begin{array}{l}\text { Chestnut } \\
\text { sponsorship }\end{array}$ & $\begin{array}{l}\text { Lucca Province, Italy } \\
\text { (Garfagna) }\end{array}$ & $\begin{array}{l}\text { Chestnut sponsor- } \\
\text { ship }\end{array}$ & Private users & $\begin{array}{l}\text { Association of } \\
\text { chestnut producers }\end{array}$ & $\begin{array}{l}\text { http://www.asso- } \\
\text { ciazionecastanicoltori.it/php/i } \\
\text { ndex.php?option=com_con- } \\
\text { tent\&view=article\&id=23\&Ite } \\
\text { mid=16 and Wiesinger } 2009\end{array}$ \\
\hline
\end{tabular}

tion of property rights is complex. When the resource is a natural landscape, the acknowledgment of the services provided by farmers is more important than the formal allocation of property rights. The value of these services is recognized, and the farmers are rewarded for the services they provide to society.

A sixth key element of the successful PESs is the introduction of limits on resource use; these limits have been directly linked to a new perception of a valuable service for the community and service users. One example is charging a fee for a permit to gather mushrooms, another is the creation of paid par- king zones to prevent congestion. These limits may be success factors because they are recognized as a guarantee of higher value and higher quality. The introduction of limits and their acceptance strengthens a PES, especially when the mechanism is well designed and the reasons behind the introduction of those limits are clearly explained. The more necessary limits are considered to be, the greater people's confidence in and support for them is.

There is a seventh element: sometimes the implementation of a PES prompts the introduction of new skills and/or the re-introduc- tion of old skills to the local population and the wider involvement of local expertise, some of which is already being applied in other business sectors. Mountain chalets and adventure parks require new skills. In other case studies, skills and activities already available in the area (such as the production of local crafts, food, wine and accommodation) have been regained, and are being used to create products and services integrated into the overall exploitation of local resources.

This integration of different skills and local business activities reveals how important local culture and the optimization of tradi-

Tab. 5 - Mushrooms and truffles gathering.

\begin{tabular}{|c|c|c|c|c|c|}
\hline $\begin{array}{l}\text { Product/ } \\
\text { Service }\end{array}$ & Location & $\begin{array}{l}\text { Marketable } \\
\text { Product/Service }\end{array}$ & Who buys & Who sells & Source \\
\hline $\begin{array}{l}\text { Mushrooms } \\
\text { gathering }\end{array}$ & $\begin{array}{l}\text { Veneto Region } \\
\text { (Italy) }\end{array}$ & $\begin{array}{l}\text { Permits for mushrooms } \\
\text { gathering }\end{array}$ & $\begin{array}{l}\text { Regional and } \\
\text { non-regional users }\end{array}$ & $\begin{array}{l}\text { Municipalities and } \\
\text { local bodies }\end{array}$ & Gatto et al. 2009 \\
\hline $\begin{array}{l}\text { Borgotaro } \\
\text { Mushrooms (a) }\end{array}$ & $\begin{array}{l}\text { Parma } \\
\text { province }\end{array}$ & $\begin{array}{l}\text { Forest management to support } \\
\text { mushroom productions }\end{array}$ & $\begin{array}{l}\text { Regional and } \\
\text { non-regional users }\end{array}$ & Local bodies & $\begin{array}{l}\text { Gatto et al. 2009, Carboni } \\
\& \text { Baratozzi } 2000\end{array}$ \\
\hline $\begin{array}{l}\text { Borgotaro } \\
\text { Mushrooms (b) }\end{array}$ & $\begin{array}{l}\text { Parma } \\
\text { province }\end{array}$ & $\begin{array}{l}\text { Protected geographical indica- } \\
\text { tion and Consortium for protec- } \\
\text { tion and improvement of } \\
\text { Borgotaro mushroom }\end{array}$ & $\begin{array}{l}\text { Regional and } \\
\text { non-regional users }\end{array}$ & Local bodies & $\begin{array}{l}\text { Gatto et al. } 2009 \text {, Carboni } \\
\& \text { Baratozzi } 2000\end{array}$ \\
\hline Truffles & Piedmont & $\begin{array}{l}\text { Forest management to support } \\
\text { truffles and sustain productions }\end{array}$ & $\begin{array}{l}\text { Regional and non- } \\
\text { regional users; and } \\
\text { intermediaries }\end{array}$ & $\begin{array}{l}\text { Activities managed } \\
\text { by provincial bodies }\end{array}$ & $\begin{array}{l}\text { http://www.re- } \\
\text { gione.piemonte.it/montagn } \\
\text { a/altre/tartufo.htm }\end{array}$ \\
\hline
\end{tabular}


tion are to the successful implementation of a PES, in addition to the strong involvement of local residents.

Other economic and financial related factors were identified as success factors. One of these is the relation between input and output. This relation is the ratio of the resources used to the economic, financial, social and idiosyncratic (identification and recognition successful elements) results. It is represented by a comparison between the amount of resources used and the effects produced by them in terms of socio-economic and financial results. This factor is particularly evident in adventure parks and mountain chalets, where private investment is most common.

In all of the case studies analyzed the creation of additional income and new jobs is important; the PESs analyzed have been implemented in rural areas, where the economy is usually underdeveloped.

Finally, two other elements to be taken into account are the introduction of innovative factors and the strong entrepreneurial drivers that developed subsequent to the introduction of PESs.

In the 28 cases studied, the identified keys to success have been grouped into five areas of impact: economic, financial, social, institutional and idiosyncratic.

All the listed elements contribute to the successful implementation of a PES mechanism: "New skills, Local participation, Culture and tradition, Input/output ratio, Income, Employment, Innovation, Entrepreneurship, Identification, Recognition, Destination, Networking, Use constraints". They have been aggregated in areas of impact according to authors analysis of the case studies. In most of the case studies there was evidence of a relationships between certain elements. Although, they can emerge as single contribution to the determine the success of the PES mechanism implementation, this relationship is reflected by the elements belonging to the same area of impact. The relationships between the areas are defined in Fig. 1.

These key elements appear crucial for the long term success of a PES. The input-output ratio falls within the financial area of impact, while income, employment, innovation and entrepreneurship belong in the economic area of impact. The generation of new skills, local participation and the enhancement of local culture and traditions are social components. Destination, use constraints and networking belong in the institutional area of impact, while the idiosyncratic area includes landscape identification and recognition.

Fig. 2 and Fig. 3 to Fig. 7 show, first in an aggregate frame and then individually, the analyzed success factors, which have been scored from 1 to 3 on the basis of their degree of presence and development in the case

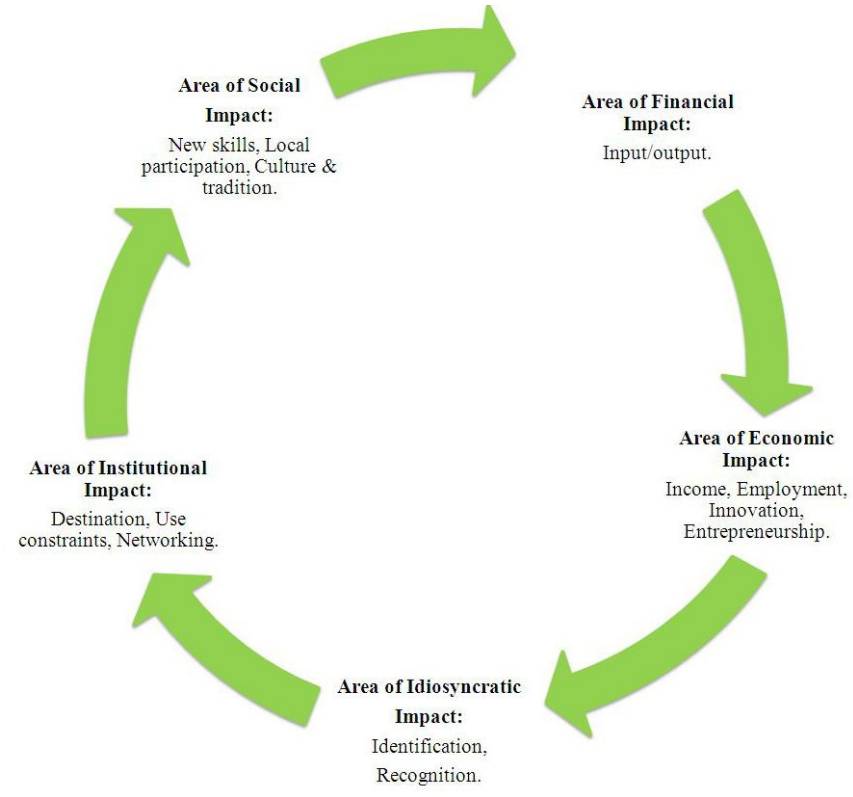

Fig. 1 - Relationship between areas of impact according to which the successful elements derived from the case study analysis can be grouped.

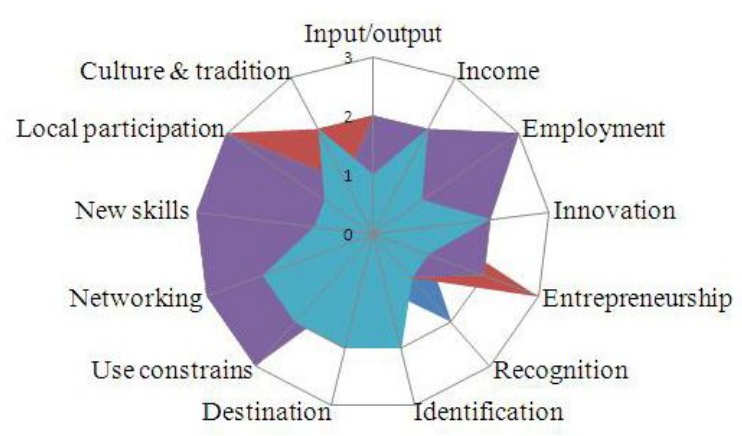

Fig. 2 - Success elements emerging from the case studies analyzed.

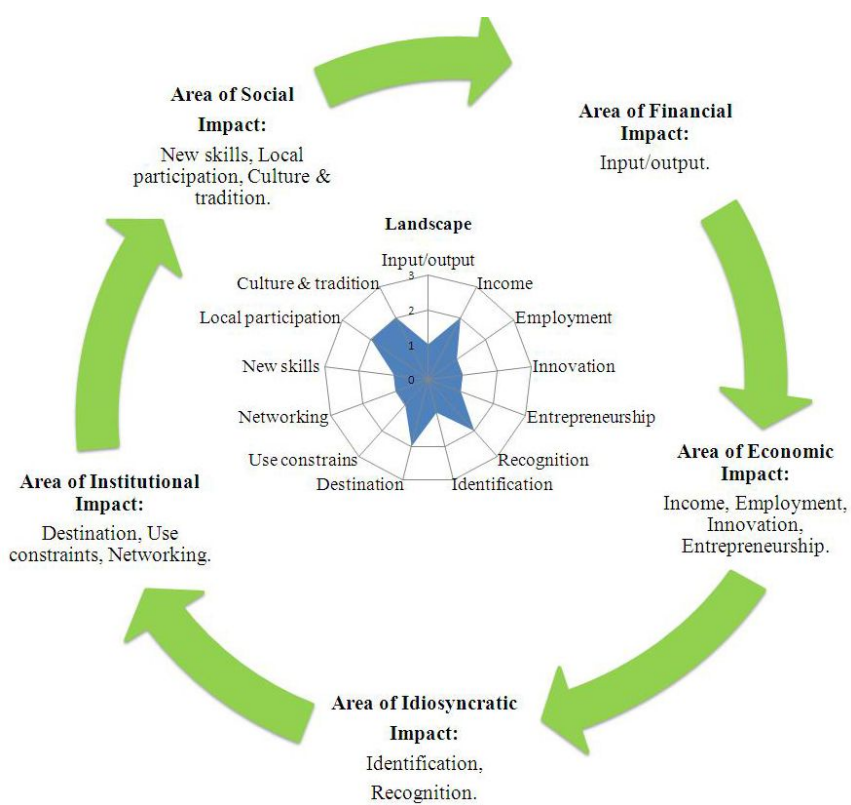

- Landscape

- Mushrooms \& truffles gathering - Mountain chalets Adventure parks - Themes trails

Fig. 3 - Success elements emerging from the case studies analyzed, distributed by impact areas: Landscape. 


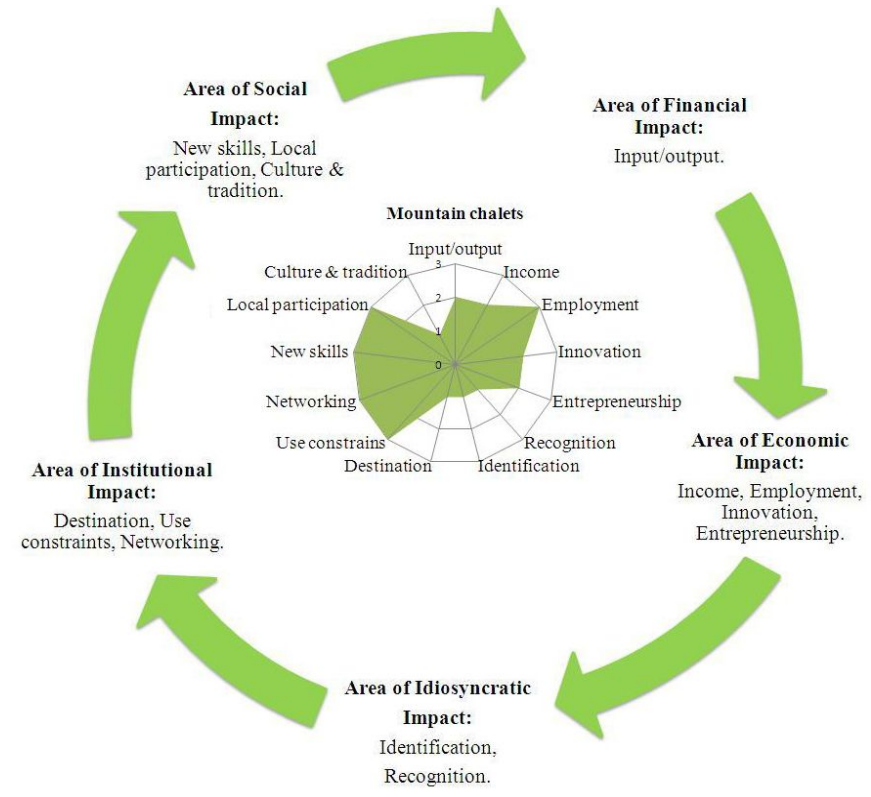

Fig. 4 - Success elements emerging from the case studies analyzed, distributed by impact areas: Mountain chalets.

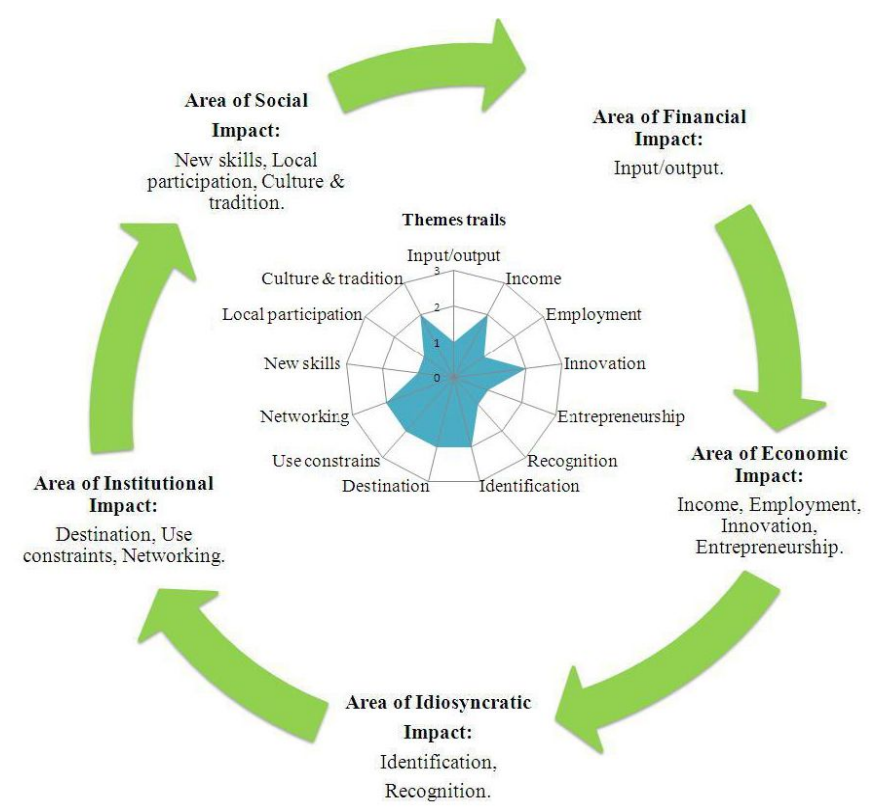

Fig. 5 - Success elements emerging from the case studies analyzed, distributed by impact areas: Theme trails. studies. The scores range from 1 to 3 , where 1 implies a minimum degree of presence, 2 a medium degree, and 3 a maximum presence; they indicate the degree of development and importance of the factor to the final PES implementation. Scores are assigned as a value of the factors developed within each case study in comparison with the others.

The radar charts give an overview of the results (Fig. 2) and of the differences between the five subsets concerned (Fig. 3,
Fig. 4, Fig. 5, Fig. 6, Fig. 7). They show the importance of the financial factor in mushroom and truffle collecting, mountain chalets and adventure parks. Radar charts are widely used to explain the dynamics between interconnected variables or factors (AlWaer et al. 2008, Bychholz et al. 2009, Bragança et al. 2010, Lescuyer 2012) and are also used in qualitative analysis (Aiello \& Donvito 2006), mainly to rank the attributes of the variables involved. The charts allow for ease and clarity of interpretation. Here we use a qualitative score to classify the success factors .

Theme trails scored highest for innovation and entrepreneurship factors.

The recognition of environmental resources as potential products and services is scored from 1 to 2 . This is best achieved in the landscape and theme trail cases, where forest resources have been integrated within a market system more effectively and profitably

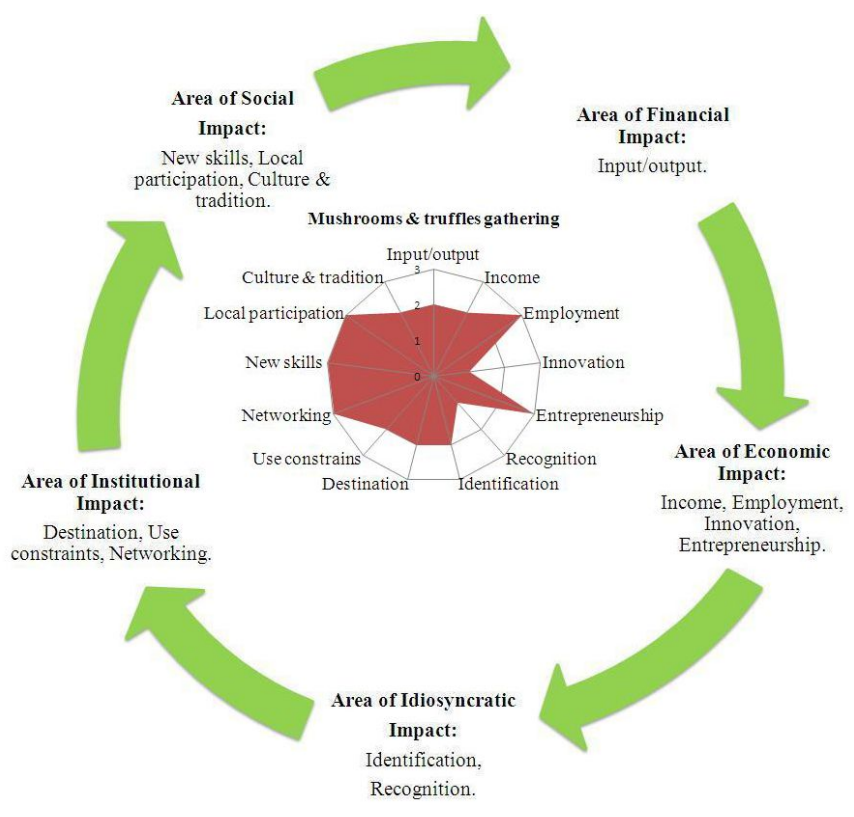

Fig. 6 - Success elements emerging from the case studies analyzed, distributed by impact areas: Mushrooms $\&$ truffles gathering.

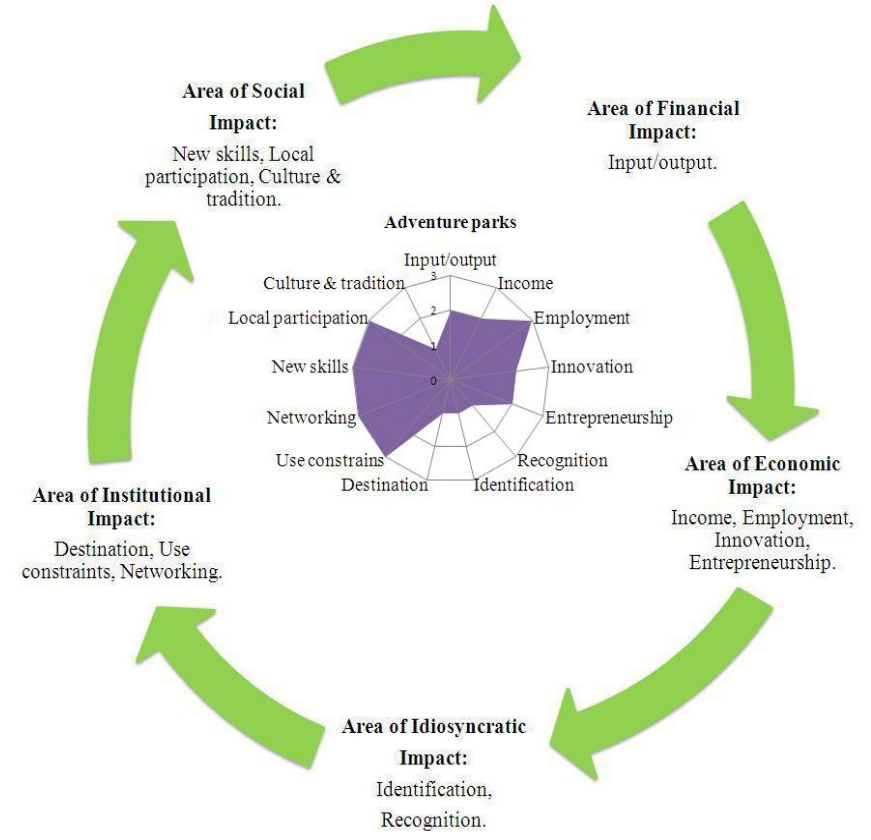

Fig. 7 - Success elements emerging from the case studies analyzed, distributed by impact areas: Adventure parks. 
than in other cases.

Within the institutional area of impact, destination is the most frequently highlighted factor in the landscape and theme trail cases. The use of limits and constraint is much more evident in the mountain chalet and adventure park cases. In almost all the case studies, skills and local participation are extremely important, as is fostering local culture and tradition.

\section{Conclusions}

Our analysis of the case studies reveals that the creation of a successful PES depends on its ability to enhance a variety of different features. Building a system that takes specific local circumstances into account is crucial, as is the possibility to introduce effective and appropriate management models. It is also important to involve local - public and private - stakeholders and to gain their support for the PES.

The fact that the PES model has not been widely adopted can be explained by a number of factors, including the objective difficulties involved in its implementation and the paucity of standard models, which means that each scheme must identify its own specific solutions. Each PES must be appropriate and relevant to its context. The dissemination and implementation of PESs will require testing and repetition and there is an inevitable risk of (varying degrees of failure.

Each PES also needs to be adapted in accordance with the product(s) and service(s) it is marketing.

\section{References}

Agrawal A, Gibson CC (1999). Enchantment and disenchantment: the role of community in natural resource conservation. World Development 27 (4): 629-649. - doi: 10.1016/S0305-750X(98) 00161-2

Aiello G, Donvito R (2006). L'evoluzione del concetto di lusso e la gestione strategica della marca. Un'analisi qualitativa delle percezioni sul concetto, sulla marca e su prodotto di lusso. Congresso Internazionale: "Le tendenze del marketing”. Università Cà Foscari (Venezia, Italy) 20 21 Jan 2006.

AlWaer H, Sibley M, Lewis L (2008). Different stakeholder perceptions of sustainability assessment. Architectural Science Review 51 (1): 4859. - doi: 10.3763/asre.2008.5107

Bragança L, Mateus R, Koukkari H (2010). Building Sustainability Assessment. Sustainability 2: 2010-2023. - doi: 10.3390/su2072010

Brown T (1984). The concept of value in resource allocation. Land Economics 60 (3): 231-246. doi: $10.2307 / 3146184$

Bychholz T, Rametsteiner E, Volk TA, Luzardis VA (2009). Multicriteria analysis for bioenergy systems assessments. Energy Policy 37: 484-495. - doi: 10.1016/j.enpol.2008.09.054

Carboni S, Baratozzi L (2000). Stato d'attuazione della pianificazione assestamentale (di gestione forestale a livello aziendale) nella regione Emilia Romagna. Sherwood 6 (3): 5-8.

Clawson M, Held B, Stoddard CH (1960). Land for the future. Johns Hopkins University Press, Baltimore, USA.

Dillman BL, Bergstrom JC (1991). Measuring environmental amenity benefits of agricultural land. In: "Farming and the Environment: An Economic Analysis of External Costs and Benefits" (Hanley $\mathrm{N}$ ed). CAB International, Wallingford, USA, pp. 250-271.

Dobbs TL, Pretty J (2008). Case study of agri-environmental payments: the United Kingdom. Ecological Economics 65: 766-776. - doi: 10.1016/j.ecolecon.2007.07.030

Elsasser P, Meyerhoff J, Montagné C, Stenger A (2009). A bibliography and database on forest benefits valuation studies from Austria, France, Germany and Switzerland - a possible base for a concerted European approach. Journal of Forest Economics 15: 93-107. - doi: 10.1016/j.jfe.2008. 03.005

Engel S, Pagiola S, Wunder S, (2008). Designing payments for environmental services in theory and practice: an overview of the issues. Ecological Economics 65: 663-675. - doi: 10.1016/j.ecolecon.2008.03.011

Frost PGH, Bond I (2008). The CAMPFIRE programme in Zimbabwe: payments for wildlife service. Ecological Economics 65: 777-788. - doi: 10.1016/j.ecolecon.2007.09.018

Gatto P, Pettenella D, Secco L (2009). Payments for forest environmental services: organizational models and related experiences in Italy. iForest 2: 133-139. - doi: 10.3832/ifor0504-002

Gios G, Clauser O (2009). Forest and tourism: economics evaluation and management features under sustainable multifunctionalty. iForest 2: 192-197. - doi: 10.3832/ifor0514-002

Goio I, Gios G (2011). Landscape-recreational value: a resource for local development-first results from a survey in a small mountain valley (Sinello Valley, Vallarsa, Northern Italy). Landscape Research 37 (3): 351-364. - doi: 10.1080/ 01426397.2011.588789

Lescuyer G (2012). Sustainable forest management at the local scale: a comparative analysis of community forests and domestic forests in Cameroon. Small-scale Forestry 1-16.

Manning R, Valliere W, Minteer B (1999). Values, ethics, and attitudes toward national forest management : an empirical study. Society and Natural Resources 12 (5): 421-436. - doi: $10.1080 / 089419299279515$

McCauley DJ (2006). Selling out on nature. Nature 443: 27-28. - doi: 10.1038/443027a

Merlo M, Milocco E, Panting R, Virgilietti P (2000). Transformation of environmental recreational goods and services provided by forestry into recreational environmental products. Forest Policy and Economics 1: 127-138. - doi: 10.1016/S1389-9341(00)00020-4

Millennium Ecosystem Assessment (2003). Millennium ecosystem assessment, ecosystems and human well-being: a framework for assessment.
Island Press, Washington, DC, USA, pp. 1-25. Muradian R, Corbera E, Pascual U, Kosoy N, May P (2010). Reconciling theory and practice: an alternative conceptual framework for understanding payments for environmental services. Ecological economics 69: 1202-1208. - doi: 10.1016/j.ecolecon.2009.11.006

Nagendra H (2011). Heterogeneity and collective action for forest management. Research Paper 2011/02, Human Development, UNEP.

Niskanen A, Slee, B, Ollonqvist P, Pettenella D, Bouriaud L, Rametsteiner E (2007). Entrepreneurship in the forest sector in Europe, University of Joensuu, Faculty of Forestry, Silva Carelica 52.

Norgaard RB (2010). Ecosystem services: from eye-opening metaphor to complexity blinder. Ecological Economics 69: 1219-1227. - doi: 10.1016/j.ecolecon.2009.11.009

Pagiola S (2008). Payments for environmental services in Costa Rica. Ecological Economics 65: 713-725. - doi: 10.1016/j.ecolecon.2007.07.033 Pettenella D, Maso D (2009). The role of networks in non-wood forest products and services marketing in Europe. In: "Modeling, Valuing and Managing Mediterranean Forest Ecosystems for Non-Timber Goods and Services" (Palahi M, Birot Y, Bravo F, Gorriz E eds). EFI Proceedings No. 57, pp. 143-156. [online] URL: http://www. efi.int/files/attachments/publications/efi_proceedings 57 net.pdf

Pettenella D, Secco L (2006). Small-scale forestry in the Italian Alps: from mass market to territorial marketing. In: Proceedings of IUFRO 3.08 Conference "Small-scale forestry and rural development: the intersection of ecosystems, economics and society" (Wall S ed). Galway-Mayo Institute of Technology, Galway (Ireland) 18-23 June 2006. COFORD, Dublin, Ireland, pp. 398-408.

Reimoser F (2005). Il ruolo della selvicoltura nella gestione faunistica. Sherwood 112: 19-23.

Tabet D (1963). La rendita fondiaria nell'agricoltura italiana, Editori Riuniti, Rome, Italy.

Turner RK, Paavola J, Cooper P, Farber S, Jessamy V, Georgiou S (2003). ANALYSIS. Valuing nature: lessons learned and future research directions. Ecological Economics 46: 493-510. doi: 10.1016/S0921-8009(03)00189-7

Van Noordwijk M, Leimona B (2010). Principles for fairness and efficiency in enhancing environmental services in Asia: payments, compensation, or co-investment? Ecology and Society 15 (4): 17.

Wiesinger HC (2009). Innovazioni turistico -ricreative nel bosco: comparazione tra Austria e Italia. Dendronatura 30(2): 10-16.

World Bank (2003). Sustainable development in a dynamic world transforming institution, growth and quality of life. World Bank and Oxford University Press, Washington, DC, USA.

Wunder S (2005). Payments for environmental services: some nuts and bolts. Occasional paper No. 42, CIFOR, Bogor, Indonesia.

Wunder S, Engel S, Pagiola S (2008). Taking stock: a comparative analysis of payments for environmental services programs in developed 
and developing countries. Ecological Economics 65: 834-852. - doi: 10.1016/j.ecolecon.2008.03. 010

Zube E (1987). Perceived land use patterns and landscape values. Landscape Ecology 1(1): 3745. - doi: 10.1007/BF02275264

Zugliani G, Dotta L (2009). Legno di risonanza

Gestione, selezione e lavorazione nelle Foreste
Demaniali di Paneveggio (TN). Sherwood 155: 14-18. 